\title{
Synergistic Effects of High Rate Algal Pond and Submerged Macrophyte Pond on Constructed Wetland for Water Purification
}

\author{
Yi Ding ${ }^{1,2}$, Yuan Sun${ }^{1}$, Daolun Feng ${ }^{1}$, Xingpo Liu', Xinshan Song* \\ ${ }^{1}$ College of Ocean Science and Engineering, Center for Marine Environmental and Ecological Modelling, \\ Shanghai Maritime University, Shanghai 201306, China \\ ${ }^{2}$ College of Environmental Science and Engineering, State Environmental Protection Engineering Center for Pollution \\ Treatment and Control in Textile Industry, Donghua University, Shanghai 201620, China
}

Received: 3 August 2020

Accepted: 8 March 2021

\begin{abstract}
This study was to assess the synergistic effects of high rate algal pond (HRAP) and submerged macrophyte pond (SMP) on constructed wetland (CW) for water purification. The results showed that algae debris and algae-macrophyte photosynthesis could promote the carbon and oxygen level while surplus algae were effectively inhibited by Vallisneria natans, thus facilitating nitrificationdenitrification and organic degradation of subsequent CW in HRAP-SMP-CW hybrid system. Water purification performance in hybrid system was significantly better than that in single HRAP, SMP and $\mathrm{CW}$ reactor. The extension of hydraulic retention time in hybrid system was conducive to higher-quality effluent. $89.4 \pm 2.5 \%$ algae biomass, $93.2 \pm 1.4 \% \mathrm{NH}_{4}-\mathrm{N}, 90.0 \pm 1.4 \% \mathrm{TN}, 99.9 \pm 0.1 \%$ TP and $92.4 \pm 2.0 \%$ COD could be reduced in hybrid system under 5d-HRT. The study demonstrated that the novel integration of pond-wetland hybrid system could be a cost-effective wastewater treatment technology.
\end{abstract}

Keywords: high rate algal pond, submerged macrophyte pond, constructed wetland, carbon and oxygen level, water purification

\section{Introduction}

Population growth and economic development in $21^{\text {st }}$ century has led to the generation of large quantities of wastewater, which always contain high levels of contaminant loads (i.e. ammonia nitrogen and organics) [1]. Uncontrolled discharge of nutrient-rich wastewaters can induce the eutrophication of natural water bodies,

*e-mail: newmountain@dhu.edu.cn especially ammonia nitrogen toxic to aquatic organisms [2]. Hence, there is an urgent need to carefully remove such pollutants in receiving water. Conventional wastewater treatment technologies (i.e. activated sludge and membrane bioreactors) typically require large investment and operation costs, which is not suitable for promotion in small and medium communities in developing countries [3]. There is an increasing awareness that wastewaters should be well treated in an economically and ecologically friendly way. In the past decades, constructed wetlands (CWs) are widely applied as a low-cost and energy-efficient technology 
to treat various wastewaters in economically undeveloped countries [4]. CW performance mainly depends on hydraulic retention time (HRT), dissolved oxygen (DO) and carbon source levels [5-7]. HRT is regarded as a crucial operating condition that ensures the effluent quality. Carbon and oxygen levels pose critical roles in nitrogen transformation via nitrificationdenitrification and degradation of organic matters, which are generally deficient due to the structure of single-stage $\mathrm{CW}$ and low $\mathrm{C} / \mathrm{N}$ characteristic of wastewaters [8]. Although external carbon addition and artificial aeration strategies have been proven effective in supplementing carbon and oxygen content, both strategies are high-cost and unsuitable for long use [910]. It is imperative to develop an economic strategy to promote $\mathrm{CW}$ performance for permanent applications.

High rate algal ponds (HRAPs) and submerged macrophyte ponds (SMPs) have been successfully applied in wastewater treatment in developing countries due to its low cost, easy operation and little maintenance [11-12]. Microalgae in HRAPs could assimilate nutrients from wastewaters and provide natural effluent oxygenation, saving energy and operational cost compared to mechanical aeration [13]. On the other hand, microalgae rich in lipids and carbohydrates could act as carbon sources for denitrification of CWs [14]. Nevertheless, surplus algae in HRAP effluent could increase the organic load of CWs. Mechanical removal of algae is time-consuming while chemical treatment pose a threat to drinking water safety [15]. Hence, it is essential to utilize the allelopathic effects from submerged macrophytes to suppress the algal growth [16]. Meanwhile, submerged macrophytes could absorb nutrients for water quality improvement and conduct oxygen transfer for nitrification and organic carbon oxidation [17]. In this study, HRAP and SMP were considered as economic and effective strategies to intensify the CW performance. The pond$\mathrm{CW}$ hybrid system provides a pragmatic option to improve the water quality through synergistic effects. However, information on the hybrid system as well as its synergistic effects was rarely mentioned. In addition, insufficient knowledge about operating strategies of the hybrid system impeded the performance intensifications. In this study, the following aspects were examined: (1) the carbon and oxygen levels and pollutant removal performance in single pond, single $\mathrm{CW}$ and hybrid system; (2) the synergistic effects of HRAP and SMP on CW for water purification; (3) the effect of HRT on hybrid system performance; and (4) the superiority and optimal operating mode of hybrid systems for efficient application.

\section{Material and Methods}

Four HRAP-SMP-CW hybrid systems were constructed in the laboratory at Donghua University in Shanghai, China $\left(38^{\circ} 39^{\prime} 27^{\prime \prime} \mathrm{N}, 104^{\circ} 04^{\prime} 58^{\prime \prime} \mathrm{E}\right)$, where the temperature was kept between $25^{\circ} \mathrm{C}$ to $35^{\circ} \mathrm{C}$. The dimension (length $\times$ width $\times$ height) of the HRAP and SMP reactor was identical with $0.96 \mathrm{~m} \times 0.60 \mathrm{~m} \times 0.60 \mathrm{~m}$. A central baffle was vertically installed in the HRAP reactor to create single-loop recirculation flow via a mechanical stirrer. Microcystis aeruginosa obtained from Institute of Hydrobiology, the Chinese Academy of Sciences, was selected as algae species. Chlorophyll a (Chl-a) content was determined as an indicator of algae biomass. A $5 \mathrm{~cm}$ layer of washed sand $(0.1-0.2 \mathrm{~cm}$ in diameter) and a $10 \mathrm{~cm}$ layer of fine gravel $(1.5-2.0 \mathrm{~cm}$ in diameter) were used to fill the bottom of SMP reactor, where submerged macrophytes (Vallisneria natans) with the similar size at a density of $7.5 \mathrm{~g} \mathrm{~L}^{-1}$ were used. Each $\mathrm{CW}$ reactor $(2.0 \mathrm{~m}$ length $\times 0.6 \mathrm{~m}$ width $\times 0.7 \mathrm{~m}$ height) planted with eight Canna indica L. consisted of three sections: influent section $(0.2 \mathrm{~m}$ $\times 0.6 \mathrm{~m} \times 0.7 \mathrm{~m})$, treatment section $(1.6 \mathrm{~m} \times 0.6 \mathrm{~m}$ $\times 0.7 \mathrm{~m})$, and effluent section $(0.2 \mathrm{~m} \times 0.6 \mathrm{~m} \times 0.7 \mathrm{~m})$. The influent and effluent sections were filled with a 65 $\mathrm{cm}$ thick layer of coarse gravel (3-4 $\mathrm{cm}$ in diameter). The middle treatment section was filled with two layers of substrate from top to bottom: a $10-\mathrm{cm}$ thick layer of washed sand (0.1-0.2 cm in diameter) and a $55-\mathrm{cm}$ thick layer of medium gravel (1-2 $\mathrm{cm}$ in diameter).

Experiments were carried out in single HRAP (Fig. 1a), single SMP (Fig. 1b), single CW (Fig. 1c) and hybrid systems A, B and C (Fig. 1d). 1d-HRT, 2d-HRT and $3 \mathrm{~d}-\mathrm{HRT}$ represented the hydraulic retention time of 1 day, 2 day and 3 day, respectively. Single HRAP, single SMP and single CW were individually operated in an intermittent way with 3d-HRT. The hybrid system A was operated in an intermittent way with 1d-HRT of HRAP, 1d-HRT of SMP and 1d-HRT of CW. The hybrid system B was operated in an intermittent way with 2d-HRT of HRAP, 2d-HRT of SMP and 1d-HRT of $\mathrm{CW}$. The hybrid system $\mathrm{C}$ was operated in an intermittent way with 1d-HRT of HRAP, 2d-HRT of SMP and 2d-HRT of CW. Unit removal of hybrid systems was calculated as following equations:

HRAP unit removal (\%)

$=\underline{\text { Influent concentration-HRAP effluent concentration }}$ Influent concentration

SMP unit removal (\%)

SMP influent concentration-SMP effluent concentration SMP influent concentration

CW unit removal (\%) CW influent concentration-CW effluent concentration

CW influent concentration

Hybrid system removal (\%)

$=\frac{\text { Influent concentration }-\mathrm{CW} \text { effluent concentration }}{}$

Influent concentration

Inlet and outlet pipes were respectively arranged on the two sides of each reactor, which could be individually switched on and off. In hybrid systems, 


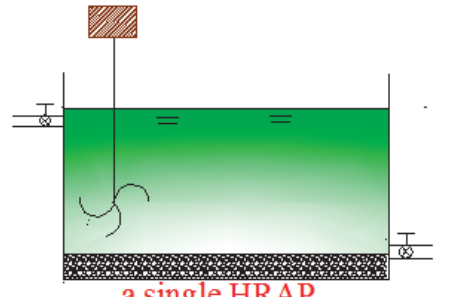

a.single HRAP

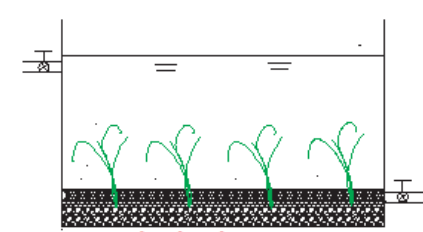

b.single SMP

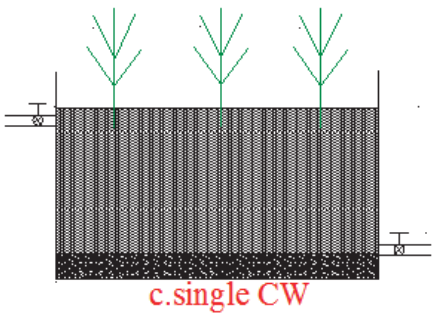

c.single CW

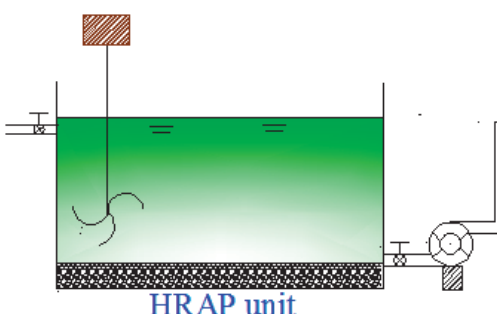

HRAP unit

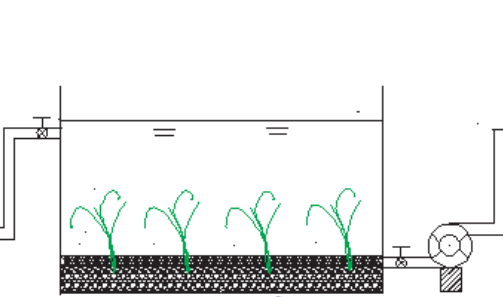

SMP unit

d.hybrid system

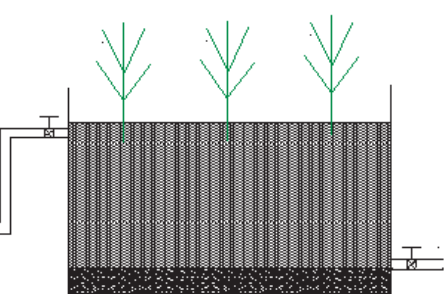

CW unit

Fig. 1. Schematic diagram of experimental reactors: single HRAP a), single SMP b), single CW c), and hybrid system d).

CW influent was fed by the SMP effluent while SMP influent was fed by the HRAP effluent through a set of connecting pipes. Synthetic wastewaters entered the HRAP reactor via peristaltic pumps to get treated, and then entered the SMP and CW reactor to obtain advanced treatment. The total inflow was $250 \pm 5 \mathrm{~L}$ within $1 \mathrm{~h}$. Characteristics of the synthetic wastewaters were shown in Table 2.

Water samples were collected from the effluent at $12 \mathrm{~h}, 24 \mathrm{~h}, 36 \mathrm{~h}, 48 \mathrm{~h}, 60 \mathrm{~h}, 72 \mathrm{~h}, 96 \mathrm{~h}$ and $120 \mathrm{~h}$ to evaluate pollutant removals and the variations of DO and COD in single reactor and hybrid systems. DO and temperature were detected using a DO meter (HI 9143, HANNA, Italy). Chl-a content was determined using a portable water quality multi-probe (Manta 2, EURERA, USA). Total nitrogen (TN), ammonia nitrogen $\left(\mathrm{NH}_{4}-\mathrm{N}\right)$, total phosphorus (TP), and chemical oxygen demand (COD) were measured using a multi-parameter colorimeter (DR900, HACH, USA).

All assays were conducted in triplicate for statistical analysis and results were presented as mean \pm standard deviation. To estimate the significant differences between data sets in this study, ANOVA tests were performed using the Origin 8.0 statistical software (OriginLab, MA, USA). Significant differences were indicated when $p$ value was below 0.05 .

\section{Results and Discussion}

Fig. 2 presents the profiles of $\mathrm{DO}$ and $\mathrm{COD}$ in experimental reactors. As shown in Fig. 2, DO level in single SMP was slightly higher than that in single CW, which was ascribed to atmospheric reaeration and plant photosynthesis in the open water of SMP. DO values decreased gradually with the competition for oxygen consumption between ammonia oxidation and organic degradation [18]. At 72-h HRT, DO detected at effluent of single SMP and CW reached $0.6 \mathrm{mg} \mathrm{L}^{-1}$ and $0.2 \mathrm{mg} \mathrm{L}^{-1}$, which was deficient to nitrification and organic degradation [19]. However, DO content increased obviously with HRT due to algal photosynthesis in single HRAP, which urgently promoted DO level of subsequent $\mathrm{CW}$ in hybrid system $\mathrm{A}$. The maximum DO in single HRAP and hybrid system A could

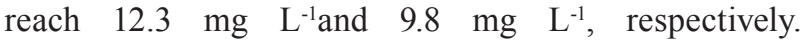
Adequate oxygen in hybrid system A profited from the combination of HRAP and SMP, which provided

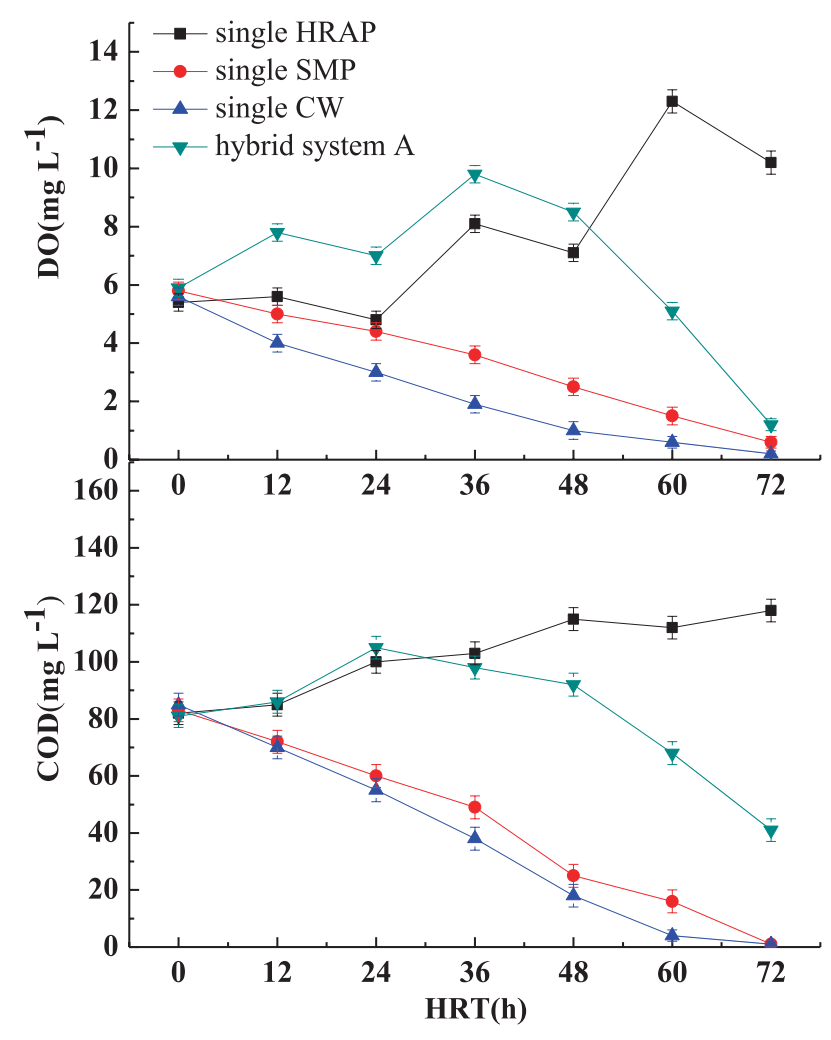

Fig. 2. Profiles of DO and COD in experimental reactors. 
aerobic environment via photosynthetic aeration of algae and submerged macrophytes.

COD values gradually decreased in single SMP and $\mathrm{CW}$. When the HRT was $72 \mathrm{~h}$, the COD content in single SMP and $\mathrm{CW}$ was close to $0 \mathrm{mg} \mathrm{L}^{-1}$, which could not provide sufficient electron donors the efficient occurrence of denitrification. However, COD content increased with HRT in single HRAP and the maximum COD reached $118 \mathrm{mg} \mathrm{L}^{-1}$ at 72-h HRT. It was mainly because algal debris could provide organic carbon, thus facilitating the increase in COD. Rich organics from the effluents of HRAP improved the carbon source level of subsequent $\mathrm{CW}$ in hybrid system A. At 72-h HRT, the COD in the effluents of hybrid system A was $41 \mathrm{mg} \mathrm{L}^{-1}$, which was significantly higher than that in single CW and SMP $(p<0.05)$. In summary, higher carbon contents in hybrid system A benefited from algae debris.

Overall treatment performance in single reactor and hybrid system A under 3d-HRT is shown in Table 1. As illustrated in Table 1, the $\mathrm{NH}_{4}-\mathrm{N}$ removal efficiencies were $40.9 \%$ in single HRAP, $45.3 \%$ in single SMP, $47.6 \%$ in single $\mathrm{CW}$, and $72.4 \%$ in hybrid system A. Nitrogen removal pathways in $\mathrm{CW}$ include plant uptake, substrate adsorption, microorganism assimilation and nitrification-denitrification, among which nitrificationdenitrification is considered as the most important mechanism for $\mathrm{N}$ reductions [20]. Although single $\mathrm{CW}$ exhibited higher $\mathrm{NH}_{4}-\mathrm{N}$ removal performance than single HRAP and SMP due to the integrated mechanisms for nitrogen removal from $\mathrm{CWs}$, the average $\mathrm{NH}_{4}-\mathrm{N}$ removal in single-stage $\mathrm{CW}$ did not exceed
$50 \%$. In contrast, $\mathrm{NH}_{4}-\mathrm{N}$ removal capacity in hybrid system A was distinctly improved, which was attributed to the synergistic effects of HRAP-SMP-CW reactors. Algae and macrophytes could assimilate $\mathrm{NH}_{4}-\mathrm{N}$ as nutrients for self-growth, which simultaneously provided adequate DO via photosynthesis for intensified nitrification occurrence of subsequent $\mathrm{CW}$. The TN removal efficiencies were $39.6 \%$ in single HRAP, 38.8\% in single SMP, $40.8 \%$ in single $\mathrm{CW}$, and $70.2 \%$ in hybrid system A. Unsatisfactory $\mathrm{TN}$ removals in single $\mathrm{CW}$ strongly indicated carbon depletion for denitrification [21]. In contrast, TN removal in hybrid system A was significantly higher than that in single $\mathrm{CW}(p<0.05)$, which was ascribed to the rich organics from algae debris of HRAP that intensified the denitrification occurrence of subsequent CW. Sedimentation, macrophyte uptake, microbial assimilation and substrate adsorption are the main mechanisms linked to phosphate removal [22]. TP reduction in single HRAP and SMP was $80.8 \%$ and $92.3 \%$, respectively. In contrast, the superior TP removal were obtained in single $\mathrm{CW}$ and hybrid system A $(p<0.05)$ due to the multiple processes for phosphorus removal, where TP could be hardly detected.

Pollution removal performance in each unit of hybrid systems under different hydraulic retention time was shown in Table 2. Algae removal in hybrid system A (35.6 $2.5 \%)$ under 3d-HRT was significantly lower than that in hybrid system B $(54.7 \pm 2.5 \%)$ and hybrid system C $(89.4 \pm 2.5 \%)$ under 5d-HRT $(p<0.05)$. The results implied that the longer retention time was conducive to SMP and CW units for removal and

Table 1. Comparison of pollution removal performance between the single reactor and hybrid system.

\begin{tabular}{|c|c|c|c|c|}
\hline Parameter & Influent ( $\left.\mathrm{mg} \mathrm{L}^{-1}\right)$ & Reactors & Effluent (mg L-1) & Removal (\%) \\
\hline \multirow{4}{*}{$\mathrm{NH}_{4}-\mathrm{N}$} & \multirow{4}{*}{$22.5 \pm 0.5$} & Single HRAP & $13.3 \pm 0.5$ & $40.9 \pm 1.4$ \\
\hline & & Single SMP & $12.3 \pm 0.5$ & $45.3 \pm 1.4$ \\
\hline & & Single CW & $11.8 \pm 0.5$ & $47.6 \pm 1.4$ \\
\hline & & Hybrid system A & $6.2 \pm 0.5$ & $72.4 \pm 1.4$ \\
\hline \multirow{4}{*}{$\mathrm{TN}$} & \multirow{4}{*}{$24.0 \pm 1.0$} & Single HRAP & $14.5 \pm 0.8$ & $39.6 \pm 1.4$ \\
\hline & & Single SMP & $14.7 \pm 0.8$ & $38.8 \pm 1.4$ \\
\hline & & Single CW & $14.2 \pm 0.8$ & $40.8 \pm 1.4$ \\
\hline & & Hybrid system A & $7.2 \pm 0.5$ & $70.2 \pm 1.4$ \\
\hline \multirow{4}{*}{ TP } & \multirow{4}{*}{$5.2 \pm 0.4$} & Single HRAP & $1.0 \pm 0.2$ & $80.8 \pm 1.0$ \\
\hline & & Single SMP & $0.4 \pm 0.1$ & $92.3 \pm 1.0$ \\
\hline & & Single CW & -- & $99.9 \pm 0.1$ \\
\hline & & Hybrid system A & -- & $99.9 \pm 0.1$ \\
\hline \multirow{4}{*}{ COD } & \multirow{4}{*}{$81.0 \pm 4.0$} & Single HRAP & $118.0 \pm 4.0$ & -- \\
\hline & & Single SMP & -- & $99.9 \pm 0.1$ \\
\hline & & Single CW & -- & $99.9 \pm 0.1$ \\
\hline & & Hybrid system A & $41.0 \pm 4.0$ & $49.4 \pm 2.0$ \\
\hline
\end{tabular}


Table 2. Pollution removal performance of the three hybrid systems.

\begin{tabular}{|c|c|c|c|c|c|c|}
\hline Parameter & Influent & & & Effluent & Unit Removal (\%) & Hybrid Removal (\%) \\
\hline \multirow{9}{*}{$\begin{array}{c}\text { Chl-a } \\
\text { (cells } \mathrm{mL}^{-1} \text { ) }\end{array}$} & \multirow{9}{*}{$580 \pm 100$} & \multirow{3}{*}{$\begin{array}{c}\text { Hybrid system } \\
\text { A }\end{array}$} & HRAP unit & $5620 \pm 60$ & -- & \multirow{3}{*}{$35.6 \pm 2.5$} \\
\hline & & & SMP unit & $4074 \pm 60$ & $27.5 \pm 2.5$ & \\
\hline & & & CW unit & $337 \pm 40$ & $91.7 \pm 2.5$ & \\
\hline & & \multirow{3}{*}{$\begin{array}{c}\text { Hybrid system } \\
\text { B }\end{array}$} & HRAP unit & $17683 \pm 60$ & -- & \multirow{3}{*}{$54.7 \pm 2.5$} \\
\hline & & & SMP unit & $5639 \pm 60$ & $68.1 \pm 2.5$ & \\
\hline & & & CW unit & $282 \pm 40$ & $90.5 \pm 2.5$ & \\
\hline & & \multirow{3}{*}{$\begin{array}{c}\text { Hybrid system } \\
\text { C }\end{array}$} & HRAP unit & $7655 \pm 60$ & -- & \multirow{3}{*}{$89.4 \pm 2.5$} \\
\hline & & & SMP unit & $2959 \pm 60$ & $61.3 \pm 2.5$ & \\
\hline & & & CW unit & $62 \pm 40$ & $97.9 \pm 2.0$ & \\
\hline \multirow{9}{*}{$\begin{array}{l}\mathrm{NH}_{4}-\mathrm{N} \\
\left(\mathrm{mg} \mathrm{L}^{-1}\right)\end{array}$} & \multirow{9}{*}{$22.5 \pm 0.5$} & \multirow{3}{*}{$\begin{array}{c}\text { Hybrid system } \\
\text { A }\end{array}$} & HRAP unit & $18.8 \pm 0.5$ & $16.3 \pm 1.2$ & \multirow{3}{*}{$72.4 \pm 1.4$} \\
\hline & & & SMP unit & $14.1 \pm 0.5$ & $25.1 \pm 1.2$ & \\
\hline & & & CW unit & $6.0 \pm 0.5$ & $57.4 \pm 1.4$ & \\
\hline & & \multirow{3}{*}{$\begin{array}{c}\text { Hybrid system } \\
\text { B }\end{array}$} & HRAP unit & $14.1 \pm 0.5$ & $36.1 \pm 1.2$ & \multirow{3}{*}{$85.9 \pm 1.4$} \\
\hline & & & SMP unit & $8.2 \pm 0.5$ & $41.9 \pm 1.2$ & \\
\hline & & & CW unit & $3.1 \pm 0.5$ & $62.2 \pm 1.4$ & \\
\hline & & \multirow{3}{*}{$\begin{array}{c}\text { Hybrid system } \\
\text { C }\end{array}$} & HRAP unit & $18.4 \pm 0.5$ & $17.2 \pm 1.2$ & \multirow{3}{*}{$93.2 \pm 1.4$} \\
\hline & & & SMP unit & $11.3 \pm 0.5$ & $38.8 \pm 1.2$ & \\
\hline & & & CW unit & $1.5 \pm 0.5$ & $86.3 \pm 1.4$ & \\
\hline \multirow{9}{*}{$\begin{array}{c}\mathrm{TN} \\
\left(\mathrm{mg} \mathrm{L}^{-1}\right)\end{array}$} & \multirow{9}{*}{$24.0 \pm 1.0$} & \multirow{3}{*}{$\begin{array}{c}\text { Hybrid system } \\
\text { A }\end{array}$} & HRAP unit & $20.5 \pm 0.8$ & $15.1 \pm 1.5$ & \multirow{3}{*}{$70.2 \pm 1.4$} \\
\hline & & & SMP unit & $17.4 \pm 1.0$ & $15.0 \pm 1.2$ & \\
\hline & & & CW unit & $7.2 \pm 0.5$ & $58.6 \pm 1.4$ & \\
\hline & & \multirow{3}{*}{$\begin{array}{c}\text { Hybrid system } \\
\text { B }\end{array}$} & HRAP unit & $15.5 \pm 0.8$ & $34.8 \pm 1.2$ & \multirow{3}{*}{$83.2 \pm 1.4$} \\
\hline & & & SMP unit & $11.1 \pm 0.8$ & $29.0 \pm 1.2$ & \\
\hline & & & CW unit & $4.0 \pm 0.8$ & $64.0 \pm 1.4$ & \\
\hline & & \multirow{3}{*}{$\begin{array}{c}\text { Hybrid system } \\
\text { C }\end{array}$} & HRAP unit & $20.2 \pm 0.8$ & $16.1 \pm 1.2$ & \multirow{3}{*}{$90.0 \pm 1.4$} \\
\hline & & & SMP unit & $14.6 \pm 0.8$ & $27.5 \pm 1.2$ & \\
\hline & & & $\mathrm{CW}$ unit & $2.4 \pm 0.8$ & $83.8 \pm 1.4$ & \\
\hline \multirow{9}{*}{$\begin{array}{c}\mathrm{TP} \\
\left(\mathrm{mg} \mathrm{L}^{-1}\right)\end{array}$} & \multirow{9}{*}{$5.2 \pm 0.4$} & \multirow{3}{*}{$\begin{array}{c}\text { Hybrid system } \\
\text { A }\end{array}$} & HRAP unit & $1.9 \pm 0.3$ & $62.9 \pm 0.8$ & \\
\hline & & & SMP unit & $0.6 \pm 0.3$ & $68.6 \pm 0.8$ & $99.9 \pm 0.1$ \\
\hline & & & $\mathrm{CW}$ unit & -- & $99.9 \pm 0.1$ & \\
\hline & & & HRAP unit & $0.9 \pm 0.2$ & $82.3 \pm 1.0$ & \\
\hline & & Hybrid system & SMP unit & -- & $99.9 \pm 0.1$ & $99.9 \pm 0.1$ \\
\hline & & & $\mathrm{CW}$ unit & -- & $99.9 \pm 0.1$ & \\
\hline & & & HRAP unit & $2.1 \pm 0.3$ & $60.8 \pm 1.0$ & \\
\hline & & Hybrid system & SMP unit & -- & $99.9 \pm 0.1$ & $99.9 \pm 0.1$ \\
\hline & & & $\mathrm{CW}$ unit & -- & $99.9 \pm 0.1$ & \\
\hline
\end{tabular}


Table 2. Continued.

\begin{tabular}{|c|c|c|c|c|c|c|}
\hline \multirow{9}{*}{$\begin{array}{c}\mathrm{COD} \\
\left(\mathrm{mg} \mathrm{L}^{-1}\right)\end{array}$} & \multirow{9}{*}{$80.0 \pm 5.0$} & \multirow{3}{*}{$\begin{array}{c}\text { Hybrid system } \\
\text { A }\end{array}$} & HRAP unit & $105.0 \pm 4.0$ & -- & \multirow{3}{*}{$49.4 \pm 2.0$} \\
\hline & & & SMP unit & $92.0 \pm 4.0$ & $8.9 \pm 2.0$ & \\
\hline & & & $\mathrm{CW}$ unit & $41.0 \pm 4.0$ & $55.4 \pm 2.0$ & \\
\hline & & \multirow{3}{*}{$\begin{array}{c}\text { Hybrid system } \\
\text { B }\end{array}$} & HRAP unit & $108.0 \pm 4.0$ & -- & \multirow{3}{*}{$83.3 \pm 2.0$} \\
\hline & & & SMP unit & $90.0 \pm 4.0$ & $16.7 \pm 2.0$ & \\
\hline & & & $\mathrm{CW}$ unit & $18.0 \pm 4.0$ & $80.0 \pm 2.0$ & \\
\hline & & \multirow{3}{*}{$\begin{array}{l}\text { Hybrid system } \\
\text { C }\end{array}$} & HRAP unit & $105.0 \pm 4.0$ & -- & \multirow{3}{*}{$92.4 \pm 2.0$} \\
\hline & & & SMP unit & $90.0 \pm 4.0$ & $14.3 \pm 2.0$ & \\
\hline & & & $\mathrm{CW}$ unit & $8.0 \pm 4.0$ & $91.1 \pm 2.0$ & \\
\hline
\end{tabular}

utilization of surplus algae. The hybrid systems B and $\mathrm{C}$ were operated with different HRT modes, which indicated that the extension of HRT in SMP and CW units contributed to the reduction of algae biomass in hybrid system. $\mathrm{NH}_{4}-\mathrm{N}$ and $\mathrm{TN}$ removal in hybrid systems $\mathrm{B}$ and $\mathrm{C}$ was significantly higher than that in hybrid system A $(p<0.05)$. This phenomenon could be explained by two facts. Firstly, the extension of HRT promoted the growth of algae and macrophytes, which facilitated the photosynthetic aeration and nitrification reaction. $\mathrm{NH}_{4}-\mathrm{N}$ could be effectively removed via nitrification process and assimilation of algae and macrophytes. Secondly, the increase in HRT was beneficial to denitrification process for enough supplement of algal carbon source [23]. Denitrification permanently removed the nitrified nitrogen from wastewaters, and TN removal in hybrid systems profited from efficient nitrification-denitrification [24]. TP removal in hybrid systems was over $99.9 \%$, which was attributed to the integrated mechanisms of hybrid systems for phosphorus removal. COD removal rate obtained in hybrid system A was $49.4 \pm 2.0 \%$, which was significantly lower than the removal rate obtained for hybrid systems B and C $(83.3 \pm 2.0 \%$ and $92.4 \pm 2.0 \%)$. Higher retention time in SMP unit of hybrid systems B and $\mathrm{C}$ promoted the manifestation of allelopathic effect on algae elimination. Additionally, higher retention time in $\mathrm{CW}$ unit of hybrid system $\mathrm{C}$ contributed to effectively degradation and utilization of algal carbon source by denitrifying microorganisms.

\section{Conclusions}

CW performance was usually limited due to insufficient carbon and oxygen level, which could be enriched by algal carbon source and algae-macrophyte photosynthesis in HRAP and SMP. SMP was conducive to ecological elimination of surplus algae while $\mathrm{CW}$ effectively utilized the algae debris for denitrification. Better performance of water purification was obtained in HRAP-SMP-CW hybrid systems due to the synergistic effects and integrated mechanisms for enhanced pollution removal. The extension of HRT in hybrid systems contributed to obtaining higher-quality effluent. The study may provide a cost-effective and eco-sustainable technology to treat eutrophic water.

\section{Acknowledgement}

This study was supported by the National Natural Science Foundation of China (grant No. 51809162) and National Key Research and Development Project (grant No. 2019YFC0408604).

\section{Conflict of Interest}

The authors have not declared any conflict of interest.

\section{References}

1. WU S.B., DONG X.L., CHANG Y.J., CARVALHO P.N., PANG C.L., CHEN L., DONG R.J. Response of a tidal operated constructed wetland to sudden organic and ammonium loading changes in treating high strength artificial wastewater. Ecol. Eng., 82, 643, 2015.

2. YANG C.T., NAN J., YU H.Y., LI J.H. Embedded reservoir and constructed wetland for drinking water source protection: Effects on nutrient removal and phytoplankton succession. J. Environ. Sci., 87, 260, 2020.

3. WU H.M., ZHANG J., NGO H.H., GUO W.S., HU Z., LIANG S., FAN J.L., LIU H. A review on the sustainability of constructed wetlands for wastewater treatment: Design and operation. Bioresour. Technol., 175, 594, 2015.

4. LUTTERBECK C.A., KIST L.T., LOPEZ D.R., ZERWES F.V., MACHADO Ê.L. Life cycle assessment of integrated wastewater treatment systems with constructed wetlands in rural areas. J. Clean Prod., 148, 527, 2017.

5. CHEN Y., WEN Y., CHENG J., XUE C.H., YANG D.H., ZHOU Q. Effects of dissolved oxygen on extracellular enzymes activities and transformation of carbon sources from plant biomass: Implications for denitrification in constructed wetlands. Bioresour. Technol., 102 (3), 2433, 2011. 
6. ZHENG X.Y., JIN M.Q., ZHOU X., CHEN W., LU D., ZHANG Y., SHAO X.Y. Enhanced removal mechanism of iron carbon micro-electrolysis constructed wetland on $\mathrm{C}, \mathrm{N}$, and $\mathrm{P}$ in salty permitted effluent of wastewater treatment plant. Sci. Total Environ., 649, 21, 2019.

7. WANG Y.H., SONG X.S., LIAO W.H., NIU R.H., WANG W., DING Y., WANG Y., YAN D.H. Impacts of inletoutlet configuration, flow rate and filter size on hydraulic behavior of quasi-2-dimensional horizontal constructed wetland: $\mathrm{NaCl}$ and dye tracer test. Ecol. Eng., 69, 177, 2014.

8. DENG L.J., NGO H.H., GUO W.S., WANG J., ZHANG H.W. Evaluation of a new sponge addition-microbial fuel cell system for removing nutrient from low $\mathrm{C} / \mathrm{N}$ ratio wastewater. Chem. Eng. J., 338, 166, 2018.

9. ZHOU X., WANG X.Z., ZHANG H., WU H.M. Enhanced nitrogen removal of low $\mathrm{C} / \mathrm{N}$ domestic wastewater using a biochar-amended aerated vertical flow constructed wetland. Bioresour. Technol., 241, 269, 2017.

10. JU X.X., WU S.B., ZHANG Y.S., DONG R.J. Intensified nitrogen and phosphorus removal in a novel electrolysisintegrated tidal flow constructed wetland system. Water Res., 59, 37, 2014.

11. KIM T., REN X.H., CHAE K.J. High-rate algal pond coupled with a matrix of Spirogyra sp. for treatment of rural streams with nutrient pollution. J. Environ. Manage, 213, 297, 2018.

12. WANG Y.H., SONG X.S., LI H.W., DING Y. Removal of metals from water using a novel high-rate algal pond and submerged macrophyte pond treatment reactor. Water Sci. Technol., 79 (8), 1447, 2019.

13. DING Y., SONG X.S., WANG W., WANG Y.H. Effects of influent algae concentrations and seasonal variations on pollutant removal performance in high-rate algae ponds. Polish J. of Environ. Stud., 27 (4), 1901, 2018.

14. BOSHOFF G., DUNCAN J., ROSE P.D. The use of microalgal biomass as a carbon source for biological sulphate reducing systems. Water Res., 38 (11), 2659, 2004.

15. BALL A.S., WILLIAMS M., VINCENT D., ROBINSON J. Algal growth control by a barley straw extract. Bioresour. Technol., 77 (2), 177, 2001.
16. ZENG L., HE F., DAI Z.G., XU D., LIU B.Y., ZHOU Q.H., WU Z.B. Effect of submerged macrophyte restoration on improving aquatic ecosystem in a subtropical, shallow lake. Ecol. Eng., 106, 578, 2017.

17. DING Y., SUN Y., TANG H.Y., SONG X.S. Effects of macrophyte species and density on algae inhibition and water purification in submerged macrophyte ponds. Polish J. of Environ. Stud., 29 (5), 3451, 2020.

18. SAEED T., SUN G.Z. A review on nitrogen and organics removal mechanisms in subsurface flow constructed wetlands: Dependency on environmental parameters, operating conditions and supporting media. J. Environ. Manage, 112, 429, 2012.

19. LIU G., HE T.Y., LIU Y.H., CHEN Z.Y., LI L.J., HUANG Q.Q., XIE Z.H., XIE Y.F., WU L.S., LIU J. Study on the purification effect of aeration-enhanced horizontal subsurface-flow constructed wetland on polluted urban river water. Environ. Sci. Pollut. Res., 26, 12867, 2019.

20. HAN Z.F., DONG J., SHEN Z.Q., MOU R., ZHOU Y.X., CHEN X.M., FU X.Y., YANG C.P. Nitrogen removal of anaerobically digested swine wastewater by pilot-scale tidal flow constructed wetland based on in-situ biological regeneration of zeolite. Chemosphere, 217, 364, 2019.

21. SAEED T., MIAH M.J., MAJED N., HASAN M., KHAN T. Pollutant removal from landfill leachate employing twostage constructed wetland mesocosms: co-treatment with municipal sewage. Environ. Sci. Pollut. Res., 27, 28316, 2020.

22. NANDAKUMAR S., PIPIL H., RAY S., HARITASH A.K. Removal of phosphorous and nitrogen from wastewater in Brachiaria-based constructed wetland. Chemosphere, 233, 216, 2019.

23. WEI D.B., SINGH R.P., LI Y.K., FU D.F. Nitrogen removal efficiency of surface flow constructed wetland for treating slightly polluted river water. Environ. Sci. Pollut. Res., 27, 24902, 2020.

24. DING X.W., XUE Y., ZHAO Y., XIAO W.H., LIU Y., LIU J.G. Effects of different covering systems and carbon nitrogen ratios on nitrogen removal in surface flow constructed wetlands. J. Clean Prod., 172, 541, 2018. 